\title{
The rising tide of ocean diseases: unsolved problems and research priorities
}

Drew Harvell ${ }^{1}$, Richard Aronson ${ }^{2}$, Nancy Baron ${ }^{3}$, Joseph Connell ${ }^{4}$, Andrew Dobson ${ }^{5}$, Steve Ellner ${ }^{1}$, Leah Gerber ${ }^{6}$, Kiho Kim ${ }^{7}$, Armand Kuris ${ }^{4}$, Hamish McCallum ${ }^{8}$, Kevin Lafferty ${ }^{4}{ }^{4}$, Bruce McKay ${ }^{10}$, James Porter ${ }^{11}$, Mercedes Pascual ${ }^{12}$, Garriett Smith ${ }^{13}$, Katherine Sutherland ${ }^{11}$, Jessica Ward ${ }^{1}$

New studies have detected a rising number of reports of diseases in marine organisms such as corals, molluscs, turtles, mammals, and echinoderms over the past three decades. Despite the increasing disease load, microbiological, molecular, and theoretical tools for managing disease in the world's oceans are underdeveloped. Review of the new developments in the study of these diseases identifies five major unsolved problems and priorities for future research: (1) detecting origins and reservoirs for marine diseases and tracing the flow of some new pathogens from land to sea; (2) documenting the longevity and host range of infectious stages; (3) evaluating the effect of greater taxonomic diversity of marine relative to terrestrial hosts and pathogens; (4) pinpointing the facilitating role of anthropogenic agents as incubators and conveyors of marine pathogens; (5) adapting epidemiological models to analysis of marine disease.

Front Ecol Environ 2004; 2(7): 375-382

$I^{\prime}$ nfectious diseases have recently caused substantial community- and ecosystem-wide impacts in marine communities. A long-spined sea urchin disease virtually eradicated urchins from the Caribbean and facilitated a coral to algal shift on many reefs (Hughes et al. 1994). Coral diseases, such as white band (Figure 1), white plague, white pox, and aspergillosis (Figure 2), have caused major changes in Caribbean reef community structure (Aronson and Precht 2001; Weil and Smith 2003; Kim and Harvell 2004). Populations of marine mammals such as seals, otters, and sea lions (Figure 3) have been heavily impacted by diseases (Kim et al. 2004), yet the community and ecosystem consequences of these mass mortalities is unknown. These acute and chronic disease events have

\section{In a nutshell:}

- An increasing incidence of disease has been detected in marine organisms such as corals, molluscs, marine mammals, turtles, and echinoderms, over the past three decades

- Spread rates appear faster in some marine epidemics than in terrestrial ones

- Controls applied for terrestrial outbreaks (quarantine, culling, vaccination) are not yet used in the ocean

- Some marine pathogens originate on land, then flow downstream into oceans

- Marine disease can alter populations and cause major changes in marine communities

${ }^{1}$ Cornell University (cdh5@cornell.edu); ${ }^{2}$ Dauphin Island Marine Lab; ${ }^{3}$ COMPASS; ${ }^{4}$ University California Santa Barbara $;{ }^{5}$ Princeton University, Princeton, NJ; ${ }^{6}$ Arizona State University, Tempe, AZ; ${ }^{7}$ American University; ${ }^{8}$ University of Queensland, Australia; ${ }^{9}$ USGS; ${ }^{10}$ Seaweb; ${ }^{11}$ University of Georgia; ${ }^{12}$ University of Michigan;

${ }^{13}$ University of South Carolina

caused serious economic losses in terms of declining fisheries revenue and ecosystem damage. Recent examples of economically destructive infectious diseases include coral diseases in the Caribbean, abalone disease in California, herpes and leptospirosis in California sea lions, lobster disease and salmon virus in Maine, and oyster protozoans in Maryland and Texas.

A 2-year effort by the Marine Disease Working Group at the National Center for Ecological Analysis and Synthesis (MDWG-NCEAS) to evaluate key issues in marine diseases focused on three problems: (1) whether disease impacts are increasing in the ocean; (2) whether current modeling and management approaches for terrestrial organisms are adequate for marine situations; and (3) developing case studies of new statistical and modeling approaches to manage marine organisms that are under disease threat. Both the impacts and prevalence of marine diseases were unusually high in recent decades, but lack of adequate baseline data makes this challenging to quantify (Harvell et al. 1999, 2002). Because of the logistical difficulties in conducting marine research and monitoring, many marine mortality events probably go undetected or are poorly understood. Often, the specific cause of the disease outbreak, whether an infectious agent (such as viruses, bacteria, fungi, protozoans, and macroparasites such as helminthes and nematodes) or non-infectious agent, has not even been identified. In addition, activities that scientists predict will increase disease occurrence are on the rise (Lafferty et al. in press). For example, ocean aquaculture increased two-fold from 1996-1998 (Pew Oceans Commission 2003); the quantities of ballast water from shipping has increased; the rate of new invertebrate introductions to the marine environment has risen; many marine fisheries are collapsing; and global temperatures 


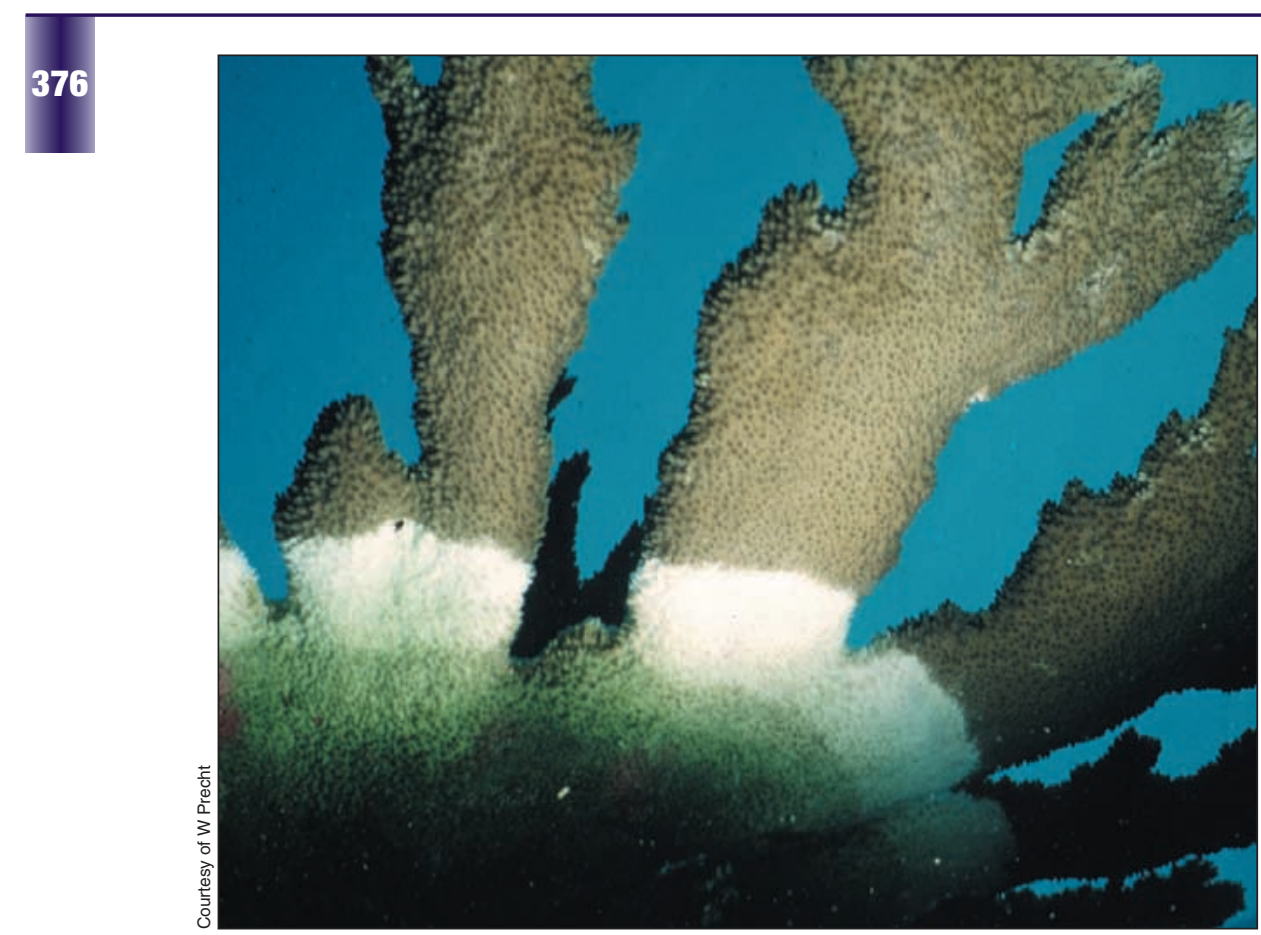

Figure 1. Caribbean elkhorn coral (Acropora palmate) infected with white band disease.

Globally, coral disease is widespread, with many new syndromes being discovered, such as those affecting plating corals of Palau (Figure 5). Thus far, the Caribbean appears to be a hot spot for disease syndromes and outbreaks (Weil and Smith 2003).

Another reliable baseline also suggests that the current high levels of damage from coral disease are unusual. Acropora cervicomis was the dominant coral on many Caribbean reefs until it was virtually eradicated by disease. The signature of this species loss, which has not occurred in the previous 3800 years, is readily detectable in recent cores (Aronson and Precht 2001).

Epidemiological models for the analysis of human disease were developed early in the 20th century (Kermack and McKendrick 1927) and were more recently adapted by Anderson and May (1979) for the study of human disease and terrestrial wildlife. Examples of new management decisions or approaches originating from modeling studies, include the decision to vaccinate dogs but

are expected to increase. Each of these activities has the potential to substantially accelerate the transmission rate of new pathogens and some will also make the hosts more susceptible.

Quantitative analysis of the scientific literature of the past three decades indicates a large increase in the number of reports about marine diseases in corals, turtles, molluscs, marine mammals, and echinoderms (Ward and Lafferty 2004; Figure 4). Lack of baseline data for marine organism diseases makes quantifying the magnitude of this increase difficult, but Ward and Lafferty's (2004) comprehensive, carefully designed quantitative study is the best estimate so far. They used literature reports as a proxy for actual events, and tested the reliability with known disease events, such as rabies outbreaks. Other groups of marine organisms, including crustaceans, seagrasses, and marine fishes, showed no proportionate increase in disease reports. Fish disease actually decreased over 30 years in agreement with expectations based on declining stocks. This literature analysis provides a quantitative basis for earlier inferences that impacts from disease are higher in the oceans of today than in the past, with the important caveat that only some taxa show a clear increase.

The MDWG concludes that the perceived burgeoning of marine disease outbreaks is real for some marine taxa, but is undetectable or not present in others (Harvell et al. 1999; Hayes et al. 2001). Corals have clearly experienced increased impacts from bleaching and disease over the past 30 years (Ward and Lafferty 2004; Figure 4). In Florida, coral cover is being lost at an escalating rate (Porter et al. 2001; Patterson et al. 2004), apparently linked to diseases such as white band (Figure 1) and aspergillosis (Figure 2), and to declining water quality. not lions for distemper to slow a distemper epidemic among Serengeti lions (Packer et al. 1999), the damping of red grouse cycles by controlling trichostrongylid worms (Hudson et al. 1998), and mapping the spread of rabies in raccoons (Smith et al. 2002). Adapting these models to the analysis of marine diseases requires an appreciation of the fundamental differences between marine and terrestrial systems and outbreaks, in particular the greater host and pathogen diversity in the ocean, the fact that transmission dynamics and spread rates may be higher in marine systems than in terrestrial systems, and that hosts in the ocean are predominantly invertebrates with shortlived, localized immunity dynamics. Management strategies, such as population viability assessments and decisions about the size and networking of marine reserves, may be dependent on the role of disease (Lafferty and Gerber 2002; McCallum et al. unpublished).

\section{Problems and priorities}

To better address the lack of information and tools for marine disease, we highlight five unsolved problems and priorities for future work.

\section{The origins and spread of most marine diseases are poorly known}

Important diseases of marine organisms can originate from aquaculture. Recent examples include infectious salmon anemia (ISA), which spread from farmed to wild populations and from Norway to Canada and Maine over several years (Ritchie et al. 2001; Murray et al. 2002); white spot syndrome virus, which affects wild and cultured penaeid 

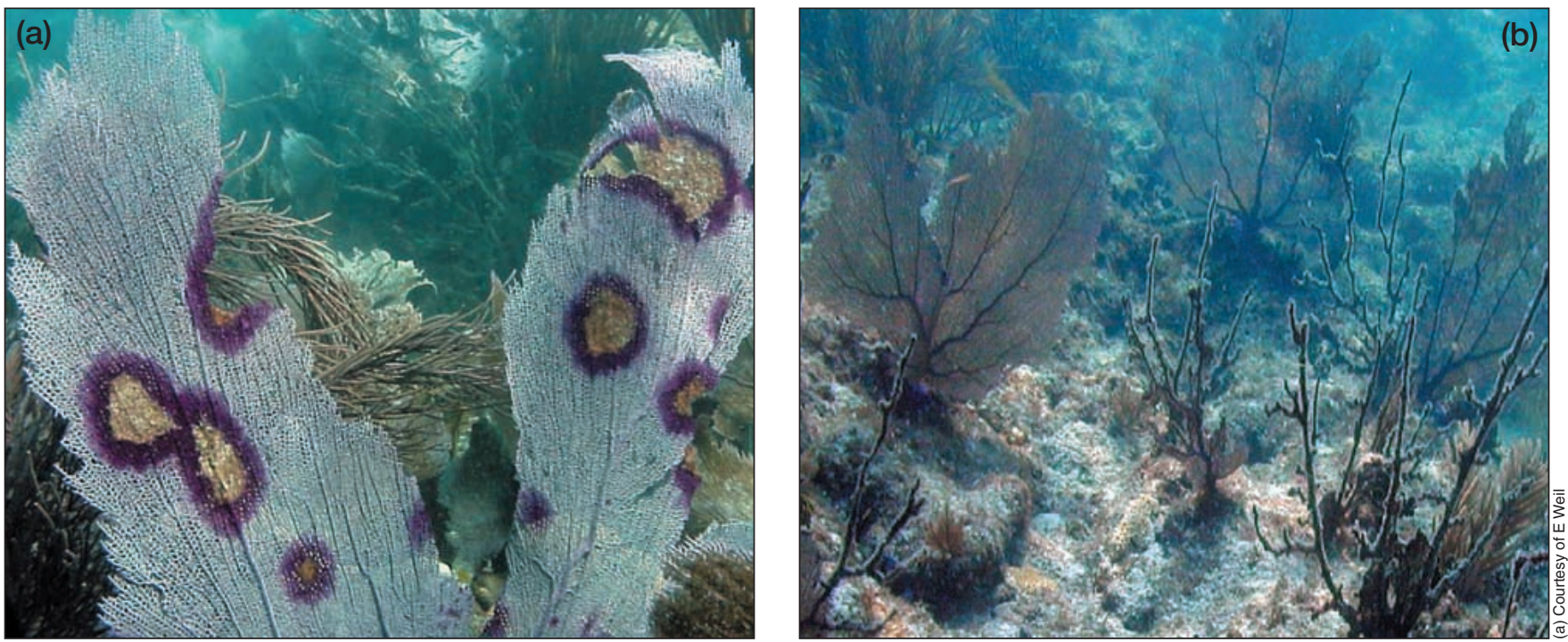

Figure 2. (a) Caribbean seafans (Gorgonia ventalina) infected with Aspergillus and (b) Sea fan skeletons killed by aspergillosis.

shrimp and spread to the Americas from Asia in 1995 (Jory and Dixon 1999); and Taura syndrome virus of white shrimp (Penaeus vannamei), which began to spread to North America from Ecuador in 1992 (Overstreet et al. 1999). There are currently no accurate estimates of the magnitude of the spillover problem for other possible pathogens, but aquaculture is a likely source of new pathogens entering wild populations in the ocean.

Ballast water is also an important potential source of pathogens that has yet to be investigated. Given the hundreds of new invertebrates and unknown numbers of microorganisms and potential pathogens introduced in ballast water, this is an urgent priority for future research.

Data on pathogen spread in the ocean are limited, but the few cases in which information is available indicate that disease may spread at least as rapidly as any terrestrial epidemic (McCallum et al. 2003). For example, a herpes epidemic in pilchards spread along the Australian coastline at approximately $10000 \mathrm{~km}$ per year (Murray et al. 2001), a bacterial infection in long-spined urchins in the Caribbean in the mid $1980 \mathrm{~s}$ spread at $3000-4800 \mathrm{~km}$ per year (Lessios 1988), and morbillivirus infection in seals spread at $3000 \mathrm{~km}$ per year (Heide-Jorgensen et al. 1992). In terrestrial environments, only the epizootics of myxomatosis and calicivirus in Australian rabbits and the virusvectored West Nile virus in North American birds have rates of spread in excess of $1000 \mathrm{~km}$ per year. Although the data are still too limited to conclude whether spread rates are really different in marine and terrestrial ecosystems, it is clear that they are extremely rapid in the ocean and in some cases may well exceed those on land.

The most likely explanation for this relatively rapid spread is the lack of barriers to dispersal in some parts of the ocean and the potential for long-term survival of pathogens outside the host. Whether these rates are the rule is uncertain; despite the impression that marine systems are quite open, studies of gene flow indicate that some marine systems are functionally more closed than they appear (McCallum et al. 2003). The findings suggest that pathogens may pose a particularly severe problem in the ocean.

Not only is spread rate in the ocean rarely measured, information on the modes of marine disease transmission is also lacking. Many terrestrial epidemics propagate via flying insect vectors, but vectored transmission in the ocean is poorly documented. One of the few known examples is a coral predator, the fireworm, that transmits Vibrio shiloi, the bacterium responsible for infectious coral bleaching (Figure 6; Sussman et al. 2003). Long-range dispersal of some marine parasites with complex life cycles occurs where migratory sea birds are the definitive hosts. Pathogen interchange between terrestrial and marine environments seems to be predominantly from land to ocean (usually via rivers), although little is known about the actual rates of pathogen exchange. For example, the

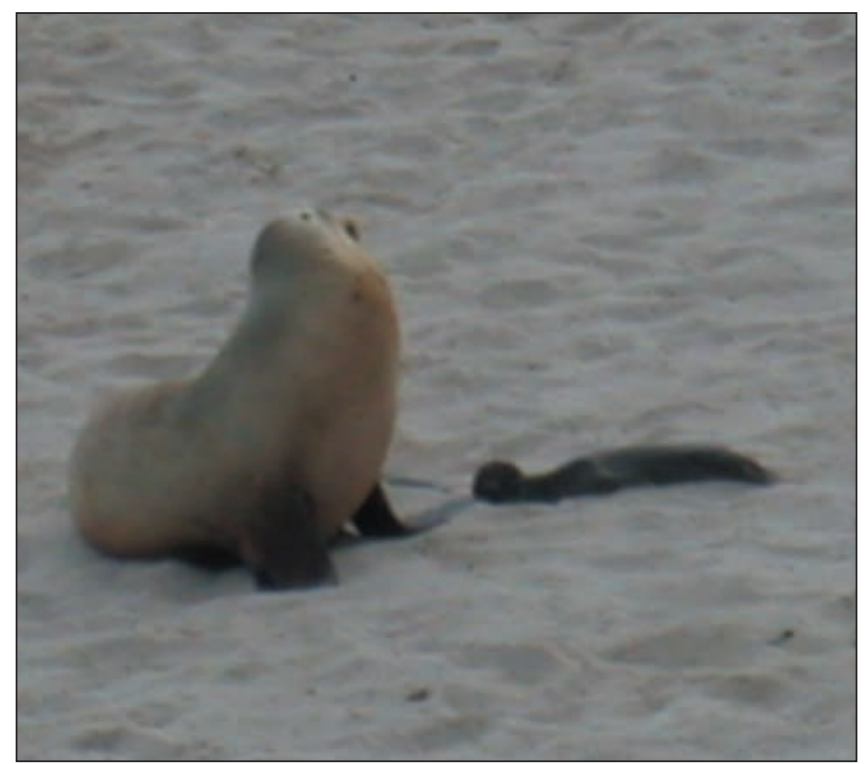

Figure 3. Sea lion with aborted pup. The probable cause was beta herpes virus. 


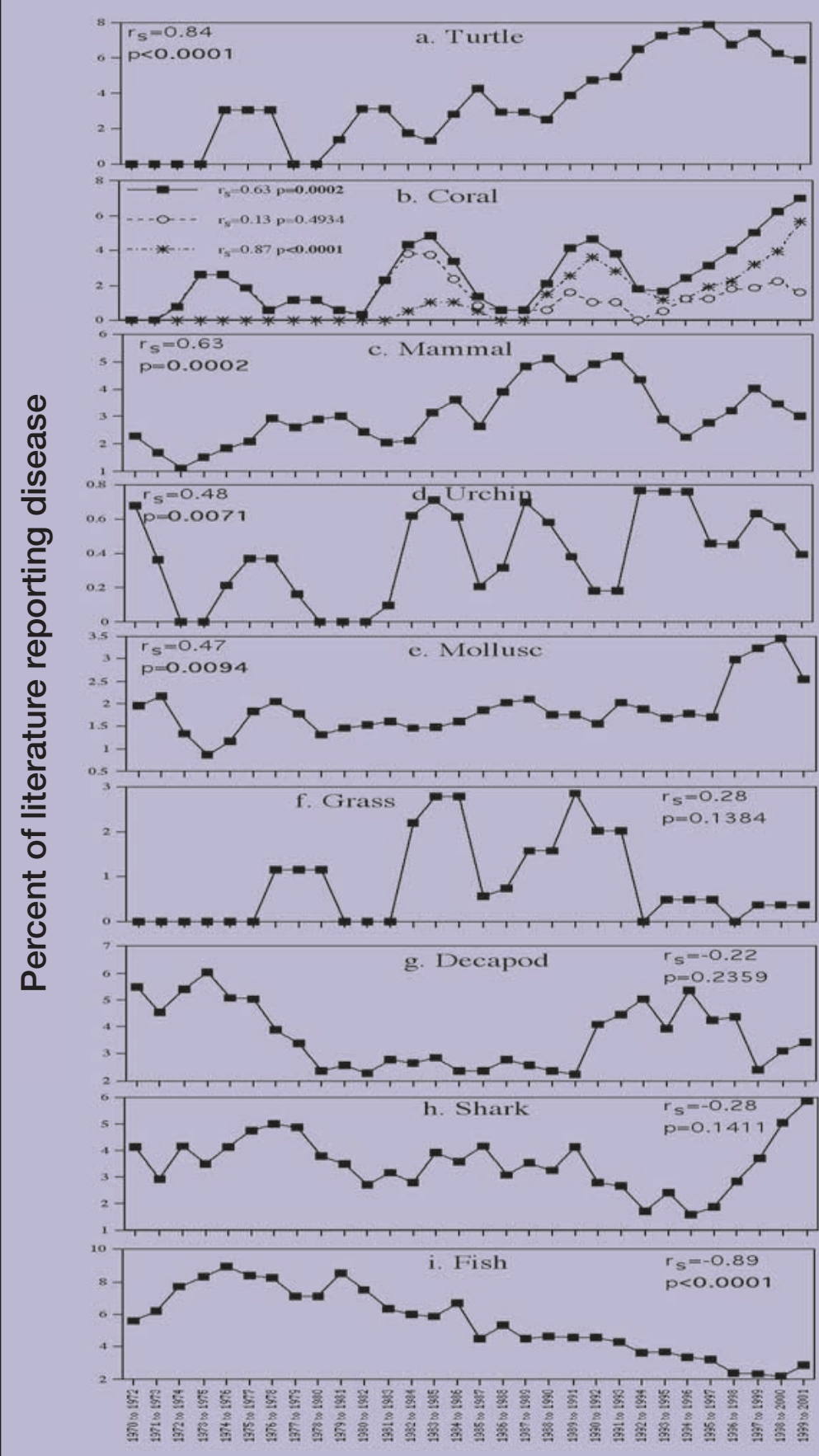

Figure 4. Thirty years of literature reports about marine diseases (from Ward and Lafferty 2004). Data for each taxon are the proportion of papers reporting disease studies for each group, normalized for total literature in each group, and plotted as 3-year running means. In each of the five taxa shown, the proportion of the literature about disease increased from 1970 to 2001. Diseases of other taxa reported in Ward and Lafferty (2004), such as fish and crustaceans, did not increase significantly over the same time interval.

parasite Toxoplasma gondii, which infects otters in Southern California, is considered an emergent disease from land because only domestic cats are known to shed infective oocysts. Otters sampled near freshwater runoff are three times more likely to be seropositive for $T$ gondii than otters that live distant from freshwater runoff (Miller et al. 2002; Cole et al. 2002). Developing evidence suggests that two coral diseases, aspergillosis and serratiosis, also originated in terrestrial ecosystems (Patterson et al. 2002; Garrison et al. 2003). Seal distemper in Lake Baikal appears to have originated from dogs, while the origins of a different strain of marine phocine distemper is still not verified (Harvell et al. 1999). Although not all marine diseases necessarily originate on land, it is important to understand that some do and others, like acanthocephalan infestations in sea otters, are affected by their host food base, which is sensitive to terrestrial influences.

The immediate research priority to ameliorate this problem is to develop molecular and microbiological diagnostics that can identify and track particular pathogen types, to trace origins and the spread of marine pathogens.

\section{Infectious stages and host range}

It is possible that some microorganisms can persist longer in marine than terrestrial conditions. Although most terrestrial bacteria do not survive for long in the marine environment, there are exceptions. Enteric bacteria are well adapted for increased salinities, but are susceptible to bacteriophage and bacteriovores like Bdellovibrio species. Bacteria that do not form spores can remain dormant in saltwater sediments for long periods and are resuspended when sediments are disturbed (Heidelberg et al. 2002). Spore-forming bacteria and fungi can remain viable for thousands of years and can be transported over tremendous distances (Moir and Smith 1990). Viruses of terrestrial origin may make up a substantial proportion of the microbial plankton (Griffin et al. 1999; Wommack et al. 1999). The survival of terrestrial microbes in estuarine environments and along shorelines can have a great impact. For example, runoff from land containing non-marine species (particularly human-associated species such as members of the Enterobacteriaceae) has necessitated the closure of beaches for extended periods of time (days to weeks), even after the primary input has subsided (Haile et al. 1999). Viable spores of normal soil fungi, including Aspergillus sydowii, which infects gorgonian corals (Figure 2) have been found in open oceanic waters and trenches.

An environmental reservoir is a habitat in which a 
pathogen survives in a viable form without its primary host. These reservoirs may be biotic, such as a secondary host in which there is no pathogenic relationship, or an alternate abiotic habitat in which the pathogen can either persist or multiply. A pathogen with an environmental reservoir has the potential to kill every member of a host species, because it is not limited by host density. Examples of such abiotic reservoirs are brackish water, estuarine sediment (for cholera), and soil. For aspergillosis in corals, airborne dust has been suggested as a reservoir (Garrison et al. 2003). Crevices in reefs appear to be reservoirs for black band disease of corals (Kuta and Richardson 2002), and some of the normal gut microbiota in humans or seagulls are possibly pathogenic to certain coral species (Patterson et al. 2002).

In addition to having environmental reservoirs, many marine pathogens have wide host ranges, allowing them to be unusually destructive. For example, coral disease outbreaks caused by generalist pathogens include black band disease, reported on 42 species from 21 genera, white plague types I and II, collectively known to infect 22 species and 16 genera (Weil and Smith 2003; Green and Bruckner 2000), and Porites pox, which affects at least 10 species of Philippine Porites (Raymundo et al. 2002). From a conservation perspective, pathogens with a wide host range are of particular concern (Lafferty and Gerber 2002); those infecting large host populations are responsible for virtually all recent disease outbreaks in endangered species (see Dobson and Foufopoulos 2001).

This problem could be mitigated by developing rapid response capability to identify, study, and manage disease outbreaks as they occur.

\section{Taxonomic diversity of hosts and pathogens}

Of the 34 animal phyla, only nine occur on land (Schubel and Butman 2000), making the potential for diverse host-parasite interactions in marine environments greater than in terrestrial ones. In addition to the greater diversity of host phyla, more classes of organisms are involved in parasitic relationships in marine environments (McCallum et al. unpublished) and hosts in the ocean include groups such as coral that have no terrestrial counterpart. Among animals, modular, clonal life forms, like corals and sponges are more common in marine environments. As hosts, modular and other clonal species may permit a build-up of more virulent disease strains, because their genetic homogeneity, coupled with the rel-

atively rapid evolution of pathogens compared to hosts, should facilitate epidemic spread of relatively virulent pathogens. This occurs among clonal terrestrial plants and where genetic variation has been restricted, such as in farmed animals and plants. The unusual colonial biology and short-lived immunity dynamics of these hosts requires modifications to the modeling framework developed by Anderson and May (1979).

Microbial diversity is also higher in marine environments, although numbers are severely underestimated because many marine microorganisms cannot be cultured. In addition, new bacterial pathogens, such as coral white plague (Aurantimonas), are being discovered in entirely new genera (Denner et al. 2003).

Research priorities here should include the development of better molecular diagnostics.

\section{Anthropogenic agents and pathogens}

The interaction of disease-resistance mechanisms with environmental stressors is reviewed briefly for corals in Mullen et al. (2004), and for other marine animals in Kim et al. (2004). Chemical contaminants, especially polychlorinated biphenyls (PCBs), DDTs, and organometals, can bioaccumulate up the food chain and are found in the tissues of marine mammals. The effects of these contaminants on endocrine function, immune competence, and carcinogenesis are well documented in laboratory rodents. Adrenal hyperplasia with associated pathology in Baltic seals has been attributed to exposure to high levels of PCBs. Both cellular and humoral immunity were reduced in harbor seals fed herring from the Baltic sea 


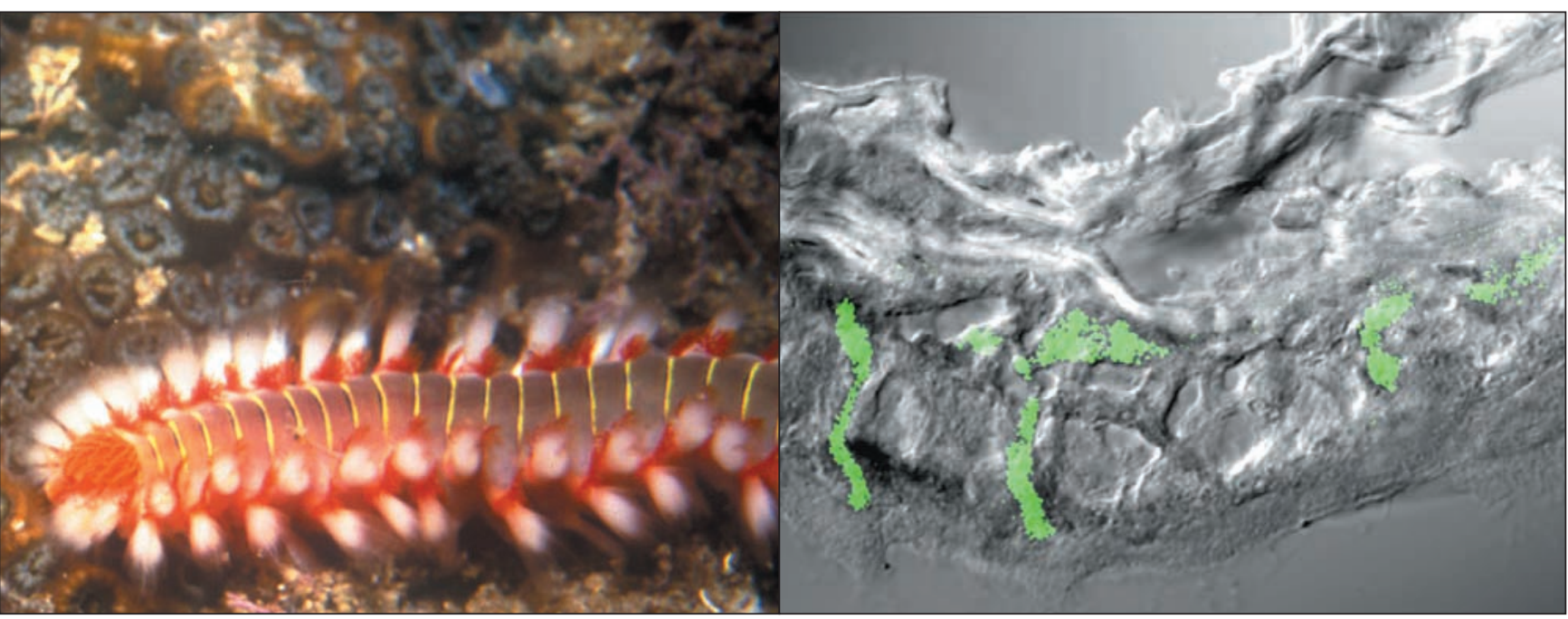

Figure 6. (a) Vectors of disease in the ocean. Hermodice carunculata feeding on Oculina (Sussman et al. 2003). (b) Photomicrograph of Hermodice gut stained with FISH probe specific for Vibrio shiloi, the pathogen causing coral bleaching (Sussman et al. 2003).

compared to immune responses in seals fed less contaminated Atlantic fish. Severity of phocine distemper in experimentally infected harbor seals was greater in animals fed diets with higher levels of PCBs (Harder et al. 1992). Contaminants have also been associated with high prevalences of Leptospira and calicivirus infections in California sea lions demonstrating premature parturition (Gilmartin et al. 1976). Experimental exposure of oysters to tributyl tin increased infection intensity and mortality.

Eutrophication due to runoff of nutrient or organic materials may also cause an increase in the abundance of diseased organisms. The best examples are for non-infectious microorganisms, such as harmful algal blooms. Pfiesteria outbreaks in North Carolina estuaries correlate with increasing eutrophication of these environments. The 2002 "blackwater" event in Florida Bay, which killed $70 \%$ of the scleractinian corals and all of the clionid sponges in long-term benthic transects on coral reefs within the Bay, occurred during a red tide event (Karenia brevis), driven by elevated nutrient conditions in the bay (Porter pers comm).

Coral reefs, especially the elkhorn coral, Acropora palmata (Figure 1), grow in oligotrophic waters, and it is hypothesized that newly elevated nutrient conditions in the Florida Keys may have contributed to the outbreak of a fecal enteric microbe that traditionally grows under such conditions (Patterson et al. 2002). Disease severity caused by seafan aspergillosis (Figure 2) sometimes correlates with lower water quality conditions, including elevated nitrogen concentrations and turbidity (Kim and Harvell 2002), but aspergillosis also occurs at pristine sites which are low in anthropogenic inputs. Aspergillotic lesions grow at a greater rate when nitrate levels are elevated (Bruno et al. 2003). Kuta and Richardson (2002) detected significantly higher nitrite concentrations at sites with black band disease (BBD) than at control sites without
BBD in the Florida Keys, but the authors emphasize how difficult the relationship between disease and water quality has been to detect on coral reefs.

A better understanding of environmental facilitators of disease and host immunity should be another research priority.

\section{Epidemiological models}

Epidemiological models developed for the study of human disease have not yet been successfully applied to ocean wildlife or management in the ocean. Adapting such models to marine organisms requires understanding fundamental differences between marine and terrestrial systems and outbreaks, including the fact that transmission dynamics and spread rates may be greater in the relatively more open ocean. Hosts in the ocean are predominantly invertebrates with short-lived immunity, so human-based models with lifetime immunity may be inappropriate. Different environmental facilitators may be predictive of marine epizootics than those on land. Initial disease modeling in marine protected areas suggests some very different patterns than on land (McCallum et al. unpublished).

A further research priority is to develop forecasting models for outbreaks with environmental or climate sensitivity. These could be modeled after crop disease and coral bleaching forecasts.

\section{Conclusions}

Measures to prevent and manage marine diseases could be as varied as the organisms and pathogens involved. Remediation strategies for infectious diseases in humans and wildlife include vaccination, antibiotic therapy, quarantine, culling, and the development of resistant transgenics. Each of these are currently ineffective (vaccina- 
tion, quarantine, culling, antibiotics) or prohibitively expensive (transgenics) in marine ecosystems. The most practical immediate remediation for many marine communities is to reduce pathogen inputs (especially from land) and synergistic stressors, such as warm temperatures and eutrophic waters. Reducing such inputs requires knowing the source of new marine pathogens - research should focus on identifying sources and reducing inputs, while at the same time developing control measures. Immunological strategies, such as vaccination or breeding of resistant strains, may be effective for marine vertebrates, as long as the specific pathogen is known. Marine invertebrate hosts also have cellular and antimicrobial responses to pathogens that could perhaps be enhanced through breeding or engineering. Implementing these approaches may be a decade away, although some breeding programs have already been successful in oysters.

Consideration of what is known about current marine diseases and what sorts of approaches have been useful on land, for both humans and wildlife, suggest the following five research priorities: (1) Develop molecular and microbiological diagnostics and capability to identify and track particular pathogen types to trace origins and spread of marine pathogens; (2) Develop rapid response capability to identify, monitor, and manage disease outbreaks as they occur; (3) Document longevity and host range of infectious stages; (4) Pinpoint the facilitating role of environment in disease outbreaks; and (5) Develop forecasting models for outbreaks that are sensitive to environmental or climatic factors.

\section{Acknowledgements}

This work was conducted as part of the Marine Disease Working Group organized by D Harvell and supported by the National Center for Ecological Analysis and Synthesis, a Center funded by NSF, the University of California, and the Santa Barbara campus. The work was initiated while Harvell was a sabbatical fellow at NCEAS and written at the Whitely Center of Friday Harbor Laboratories. Special thanks to Patty Debenham at Seaweb for her insights and to Harvell's lab group at Cornell for comments.

\section{References}

Anderson RM and May R. 1979. Population dynamics of infectious disease. Nature 280: 361.

Amos K and Thomas JA. 2002 Disease interactions between wild and cultured fish: observations learned from the Pacific Northwest. Bull Eur Fish Pathol 22: 95-102.

Aronson RB and Precht WF. 2001. White band disease and the changing face of Caribbean coral reefs. Hydrobiologia 460: 24-38.

Bruno JF, Petes LE, Harvell CD, and Hettinger A. 2003. Nutrient enrichment can increase the severity of coral diseases. Ecol Lett 6: 1056-61.

Cole RA, Lindsay D, Howe DK, et al. 2002. Biological and molecular characterizations of Toxoplasma gondii strains obtained from southern sea otters (Enhydra lutris nereis). J Parasitol 3: 526-30

Denner EBM, Smith G, Busse H-J, et al. 2003. Characterisation of the bacterial pathogen, WP1, the causative agent of Plague type II disease of Caribbean scleractinian corals: description of Aurantimonas coralicida. Int J Syst Evol Micr 53: 1115-22.

Dobson A and Foufopolous J. 2001. Emerging infectious pathogens of wildlife. Philos T Roy Soc B 1411: 1001-12.

Ford SE. 1996. Range extension by the oyster parasite Perkinsus marinus into the Northeastern United States: response to climate change? J Shellfish Res 15: 45-56.

Garrison VH, Shinn EA, Foreman WT, et al. 2003. African and Asian dust: from Desert soils to coral reefs. BioScience 5: 469-80.

Gilmartin WG, DeLong RL, Smith AW, et al. 1976. Premature parturition of the Callifornia sealion. J Wildlife Dis 12: 104-15.

Green E and Bruckner AW. 2000. The significance of coral disease epizootiology for coral reef conservation. Biol Conserv 96: 347-61.

Griffin DW, Gibson CJ, Lipp EK, et al. 1999. Detection of viral pathogens by reverse transcriptase PCR and of microbial indicators by standard methods in the canals of the Florida Keys. Appl Environ Microb 65: 4118-25.

Haile R, Witte J, Gold M, et al. 1999. The health effects of swimming in ocean water contaminated by storm drain runoff. Epidemiology 10: 355-63.

Harder TC, Wilhus T, Leibold W, and Liess B. 1992. Investigations on the course and outcome of phocine distemper virus infection in harbor seals (Phoca vitulina) exposed to polychlorinated biphenyls. J Vet Med B 39: 19-31.

Harvell CD, Kim K, Burkholder JM, et al. 1999. Emerging marine diseases - climate links and anthropogenic factors. Science 285: 1505-10.

Harvell CD, Mitchell C, Ward J, et al. 2002. Climate warming and disease risks for terrestrial and marine biota. Science 296: 2158-62.

Harvell CD, Mullen K, and Peters E. Coral resistance to disease. In: Rosenberg E (Ed). Coral health and disease. Tel Aviv, Israel: Tel Aviv Press. In press.

Hasson KW, Lightner DV, and Mari J. 1999. The geographic distribution of Taura Syndrome Virus (TSV) in the Americas: determination by histopathology and in situ hybridization using TSV-specific cDNA probes. Aquaculture 171: 1-2.

Hayes ML, Bonaventura J, Mitchell TP, et al. 2001. How are climate and marine biological outbreaks functionally related? Hydrobiologia 460: 213-20.

Heidelberg JF, Heidelberg KB, and Colwell RR. 2002. Seasonality of Chesapeake Bay bacterioplankton species. Appl Environ Microb 68: 5488-97.

Herbst LH. 1994. Fibropapillomatosis of marine turtles. Annu Rev Fish Dis 4: 389-425.

Heide-Jorgensen MP, Harkonen T, Dietz R, and Thompson PM. 1992. Retrospective of the 1988 European seal epizootic. Dis Aquat Organ 13: 37-62.

Hoegh-Guldberg O. 1999. Climate change, coral bleaching and the future of the world's coral reefs. Mar Freshwater Res 8: 839-66.

Hudson PJ, Dobson AP, and Newborn D. 1998. Prevention of population cycles by parasite removal. Science 282: 2256-58.

Hughes T. 1994. Catastrophes, phase shifts, and large scale degradation of a Caribbean coral reef. Science 265: 1547-51.

Jolles A, Sullivan P, Alker AP, and Harvell CD. 2002. Disease transmission of aspergillosis in sea fans: inferring process from spatial pattern. Ecology 9: 2373-78.

Jones JB, Hyatt AD, Hine PM, et al. 1997. Special topic review: Australasian pilchard mortalities. World J Microb Biot 13: 383-92.

Jory DE and Dixon HM. 1999. Shrimp whitespot virus in the western hemisphere. Aquacult Mag 25: 83-91.

Kermack WO and McKendrick WG. 1927. A contribution to the mathematical theory of epidemics. P Roy Soc Lond A 115: $700-21$. 
Kim K and Harvell CD. 2002. Aspergillosis of sea fan corals: disease dynamics in the Florida Keys, USA. In: Porter J and Porter $\mathrm{K}$ (Eds). Linkages between ecosystems in the South Florida hydroscapes. Boca Raton, FL: CRC.

Kim, K. and Harvell, C.D. 2004. The rise and fall of a seven year seafan-fungal epizootic. Am Nat. in press.

Kim K, Dobson A, Gulland FMD, and Harvell CD. 2004. Disease and the conservation of marine diversity. In: Norse $\mathrm{E}$ and Crowder L (Eds). Conservation of marine ecosystems. Washington DC: Island Press.

Kuta KG and Richardson LL. 2002. Ecological aspects of black band disease of corals: relationships between disease incidence and environmental factors. Coral Reefs 21: 393-98.

Lafferty KD and Gerber L. 2002. Good medicine for conservation biology: the intersection of epidemiology and conservation theory. Conserv Biol 16: 593-604.

Lafferty K, Porter J, and Ford S. Are diseases increasing in the ocean? Ann Rev Ecol Evol Sys. In press.

Lessios HA, Robertson DR, and Cubit JD. 1984. Spread of Diadema antillarum mass mortality through the Caribbean. Science 226: 335-37.

Lessios HA. 1988. Mass mortality of Diadema antillarum in the Caribbean: what have we learned? Annu Rev Ecol Syst 19: 371-93.

McCallum H, Harvell CD, Dobson A. 2003. Rates of spread of marine pathogens. Ecol Lett 12: 1062-67.

McCallum H, Gerber LR, and Jani A. Does infectious disease influence the efficacy of marine protected areas? A theoretical framework. In preparation.

Miller MA, Gardner IA, Krueder C, et al. 2002. Coastal freshwater runoff is a risk factor for Toxoplasma gondii infection of southern sea otters (Enhydra lutris nereis). Int J Parasitol 32: 997-1006.

Moir A and Smith DA. 1990. The genetics of bacterial spore germination. Annu Rev Microbiol 44: 531-54.

Mullen K, Peters E, and Harvell CD. 2004. Coral resistance to disease. In: Rosenberg E (Ed). Coral health and disease. Berlin: Springer-Verlag Press.

Murray AG, O'Callaghan M, and Jones B. 2002. Simple models of massive epidemics of herpesvirus in Australian (and New Zealand) pilchards. Environ Int 27: 243-48.

Overstreet RM, Lightner DV, Hasson KW. 1999. Susceptibility to Taura syndrome virus of some penaeid shrimp species native to the Gulf of Mexico and the southeastern United States. J Invertebr Pathol 2: 165-76.

Packer C, Altizer S, Appel M, et al. 1999. Viruses of the Serengeti: patterns of infection and mortality in African lions. J Anim Ecol 68: 1161-78.

Patterson KL, Porter JW, Ritchie KB, et al. 2002. The etiology of
White Pox, a lethal disease of the Caribbean elkhorn coral, Acropora palmate. P Natl Acad Sci USA 13: 8725-30.

Patterson KL, Porter JW, Torres C. 2004. Disease and immunity in Caribbean and Indo-Pacific zooxanthellate corals. Mar Ecol Progr Ser 266: 273-302.

Porter JW, Dustan JP, Japp WC, et al. 2001. Patterns of spread of coral disease in the Florida Keys. Hydrobiologia 460: 1-24.

Palumbi SR, Gaines S, and Warner R. 2003. New technology in development of marine reserves. Front Ecol Environ 2: 73-79.

Pew Oceans Commission. 2003. America's living oceans: charting a course for sea change. A report to the nation. Arlington, VA: Pew Oceans Commission.

Raymundo LJ, Harvell CD, and Reynolds T. 2002. Porites ulcerative white spot disease: description, prevalence, and host range of a new coral disease affecting Indo-Pacific reefs. Dis Aquat Organ. In press.

Rice TD, Williams HN, and Turny BF. 1998. Susceptibility of bacteria in estuarine environments to autochthonous bdellovibrios. Microb Ecol 35: 256-64.

Ritchie RJ, Cook M, Melville K, et al. 2001. Identification of infectious salmon anemia virus in atlantic salmon from Nova Scotia: evidence for functional strain differences. Dis Aquat Organ 44: 171-78.

Schubel JR and Butman CA. 2000. Keeping a finger on the pulse of marine biodiversity: how healthy is it? In: Raven $\mathrm{PH}$ and Williams T (Eds). Nature and human society: the quest for a sustainable future. Washington DC: National Academy Press.

Smith DL, Lucey B, Waller LA, et al. 2002. Predicting the spatial dynamics of rabies epidemics on heterogeneous landscapes. $P$ Natl Acad Sci USA 99: 3668-72.

Sussman M, Loya Y, Fine M, and Rosenberg E. 2003. The marine fireworm Hermodice carunculata is a winter reservoir and spring-summer vector for the coral-bleaching pathogen Vibrio shiloi. Environ Microb 5: 250-55.

Ward JR and Lafferty K. 2004. The elusive baseline of marine disease: are marine diseases in ocean ecosystems increasing? PLoS Biol 2: 0542-47.

Weil E and Smith G. 2003. Scleractinian and octocoral disease Caribbean-wide. In: Kasim MK, Moosa, Soemodihardjo S, et al.(Eds). Proceedings of the Ninth International Coral Reef Symposium: 23-27 Oct 2000: Bali, Indonesia.

Wilcox RM and Fuhrman JA. 1994. Bacterial viruses in coastal seawater: lytic rather than lysogenic production. Mar Ecol Prog Ser 114: 35-45.

Wommack KE, Ravel J, Hill RT, et al. 1999. Population dynamics of Chesapeake Bay virioplankton: total community analysis by pulsed-field gel electrophoresis. Appl Environ Microbiol 65: 231-40. 